\title{
Development of Smart and Sustainable Economy in the European Union
}

\author{
NikiDerlukiewicz ${ }^{1}, \mathrm{PhD}$
}

\begin{abstract}
Innovations are very important in the development of the modern economy and are the major factor in proving the competitiveness of enterprises, as well as national and regional economies. Although the EU market is the one of the largest in the world, it is not sufficiently innovation-friendly. Currently Europe is facing many challenges associated for example with exhaustible natural resources, climate change, an aging population and increasing competition from the United States. Europe needs more investment in research and development to support the competitiveness of its industry and to improve its research and innovation system. Public and private investments in R\&D are crucial to enable Europe to take advantage of any rebound in the economy.

One of the European solutions to deal with these problems, is the new strategy dedicated to help socio-economic development of the European Union - Europe 2020. The new strategy for Europe 2020 emphasizes the need for member states to undertake joint action, which would help to overcome the crisis and implement reforms enabling them to face and deal with different problems. In order to achieve the above objectives some fundamental priorities were included in the strategy, i.e: smart and sustainable growth.

The aim of this article is to present general guidelines for the development of smart and sustainable economy in the European Union in the context of current policy, strategic documents as well as activities and projects.
\end{abstract}

Key words: smart, sustainable, development, strategy

\section{Introduction}

A number of structural changes and new tendencies in social and economic development can be observed in the contemporary economy. The most current process is globalization, which is expressed in theprogressing mutual dependence and international integration of national economies on a global scale. Globalization gives people the opportunity to travel, communicate and invest internationally. It also allows global production and consumption. Moreover, globalization is associated with rapid development of electronic information and transportation systems (Wells, Shuey,Kiely, 2001).

Another important process in the contemporary economy is the scientific and technological evolution, which is accelerated by the fact that people have accepted the superiority of factors such as knowledge, research and innovations. Thus, we can 
observe the development of a knowledge-based economy. The term knowledge-based economy implies the recognition of the role of knowledge and information and technology in socio-economic growth. World's economies have become much more dependent on the production, distribution and use of knowledge than ever before (OECD, 1996) Today, owing to information and communication technologies, it is possible to store and transfer knowledge and information at quite low costs.(Kuhn, Tomassini, Simons, 2006)

Knowledge and innovations are considered the key sources of growth and development in the global economy (Runiewicz-Wardyn, 2008) Therefore, contemporary economies of most countries and regions display a strong trend towards development of knowledge-based economy, with knowledge and innovation perceived as the main factors boosting competitiveness and socio-economic advance (Węgrzyn, 2008). It is often emphasized that the most important feature of economic competitiveness is innovation, i.e. the introduction of modern concepts and solutions into the field of technology, production, management and organization, with the view of transforming them into commercial products and services (Kukliński, 2001).Innovation is at the core of the efforts to change Europe's economy and society towards a resource-efficient and low-carbon future. The promotion of innovation for sustainable growth needs a holistic approach and a long-term perspective across the policy cycle (European Commission, 2012).

The European Union tries to meet the challenges of globalization and make the European economy one of the most competitive in the world. The way to achieve this is through supporting smart growth. This approach is a result of the Lisbon Strategy adopted in 2000 (and updated in 2005), which was a strategic program of socioeconomic development of the European Union. According to this program, the EU would become the most competitive and dynamic knowledge-based economy in the world. Another strategy for Europe for the next ten years proposed by the European Commission on March 3, 2010: 'Europe 2020 - a European strategy for smart, sustainable and inclusive growth' aims at increasing innovativeness in Europe (MempelŚnieżyk, 2013).

The new strategy for Europe 2020 emphasizes the need for Member States to undertake joint action, which would help to overcome the crisis and implement reforms enabling them to face and deal with diverse problems. There are three fundamental priorities included in the strategy:

- smart growth -growth based on education (encouraging people to learn, study and update their skills), research and innovation (creating new products and services that generate growth and jobs and help address social challenges) and digital society (using information and communication technologies),

- sustainable growth - growth based on a more competitive low-carbon economy that makes efficient, sustainable use of resources, protection ofthe environment (by reducing emissions and preventing biodiversity loss), capitalization on Europe's leadership in developing new green technologies and production methods as well as on the introduction of efficient smart electricity grids, 
- $\quad$ inclusive growth - based on the increase in Europe's employment rate (more and better jobs, especially for women, young people and senior workers), help for people of all ages to anticipate and manage change through investment in skills and training, modernization of labor markets and welfare systems.(European Commission, 2010).

In Europe 2020 strategy there are seven flagship initiatives(presented in fig.1), which will help to accomplish the objective ofdeveloping smart, sustainable and inclusive growth in the EU.

\section{EUROPE 2020}

\section{FLAGSHIP INITIATIVES}

\section{PRIORITIES}

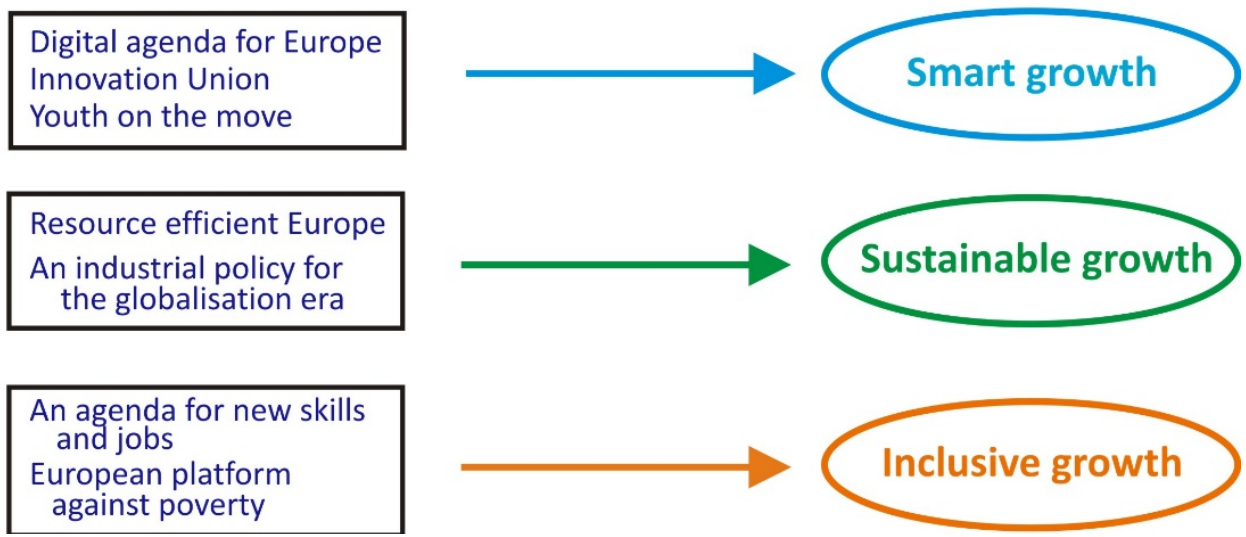

Figure 1. Flagship initiatives and priorities of the Europe 2020 strategy

Source: Own study based on:European Commission (2010), bttp:/ / ec.europa.eu/ europe2020

The aim of the article is to present general guidelines for the development of a smart and sustainable economy in the European Union in the context of current policies, strategic documentsi.e. flagship initiativesof Europe 2020 strategy as well as the ongoingactivities and projects.

\section{Theoretical aspect of smart and sustainable development}

The most popular definition of sustainable development is the definition of the United Nations, which emphasizes that "sustainable development is development that meets the needs of the present without compromising the ability of future generations to meet their own needs". (WCED, 1987)

Commonly, development consist of a progressive change in the economy and society and the satisfaction of human needs. However, living standards that go beyond the minimum are sustainable only if consumption standards have regard for long-term sustainability. Today, still most of us live beyond the world's ecological means, for example in our patterns of energy use. Perceived needs are socially and culturally determined, and sustainable development requires the promotion of standards that 
encourage consumption to remain within the bounds of the ecological potential and to which all can reasonably aspire.

It should be highlighted that sustainable development advises that the needs of the future can be met depending on how well social, economic, and environmental objectives or needs are balanced. Very often needs are contradictory and some example of these needs are presentedin fig.2.For instance, industrial growth may be in conflict with the protection of natural resources.

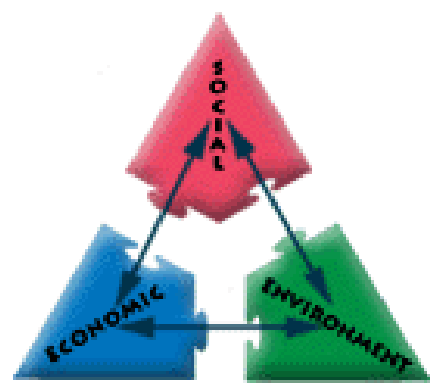

\begin{tabular}{|r|c|l|}
\hline Services & Equity & Biodiversity \\
Household Needs & Participation & Natural Resources \\
Industrial Grow th & Empowerment & Camping Capacity \\
Agricultural Grow th & Social Mobility & Ecosystem Inteqrity \\
Efficient Use of Labor & Cultural Preservation & Clean Air and Water \\
\hline
\end{tabular}

\section{Figure 2. Needs in three main domains of sustainable development}

Source: http:// wown.worldbank.org/depweb/english/sd.html

The three pillars of sustainable development - economic growth, environmental management, and social inclusion are crucial andoccur across all sectors of development, from cities facing fast urbanization process, infrastructure, energy development and use, water availability, as well as transportation(Girardet, 1999).

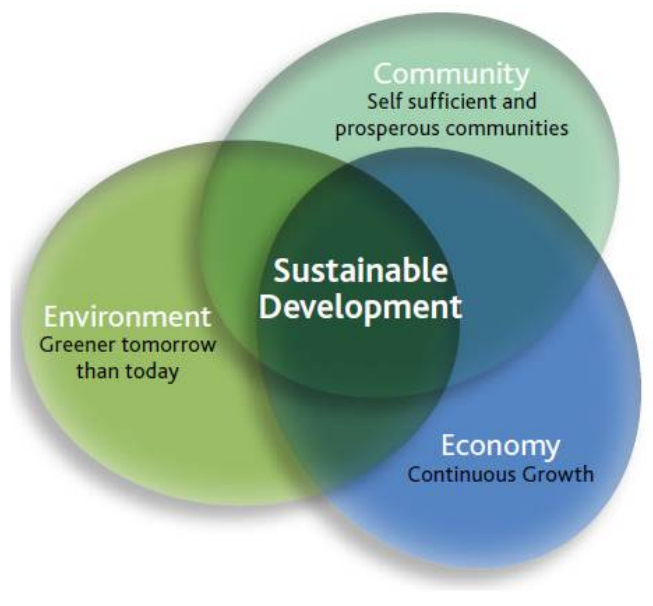

Figure. 3. Components of sustainable development

bttps:/ / www.lynascorp.com/Pages/zero-harm-andsustainable-development.aspx 
Cities are implementing low-carbon growth and public transportation. Agriculturalists are picking up the practices of climate-smart agriculture. Countries are identifying the value of their natural resources, and industries are appreciating how much they can save thanks to energy and supply chain efficiency.

Today sustainable development is thechallenge facing countries, cities, corporations, and organizations(World Bank, 2012). Additionally, in the European Union member states and regions, sustainable development plays an important role in the socio-economic policy and future development.

The new Europe 2020 strategy emphasizes that future development of the whole Community should be based on smart, sustainable and inclusive growth. It is worth noting that smart development means improving education, research and innovation and creating adigital society, where most of the people use information and communication technologies. The most important goals for smart growth concern:

- combined public and private investment in R\&D to reach 3\% of EU's GDP,

- 75\% employment rate for women and men aged 20-64 by 2020 - achieved by getting more people to work, especially women, the young, older and low-skilled people, - better educational achievements (European Commission,2010).

\section{Flagship initiatives of Europe 2020 Strategy for development of a smart and sustainable economy}

To achieve the goals of the Europe 2020 strategy,seven flagship initiatives were identified (as a part of strategy). Five of these initiatives concern the development of a smart and sustainable economy: Innovation Union, Digital agenda for Europe, Youth on the move, Resource efficient Europe, An industrial policy for the globalization era and theywill be discussed in the article.

The main aim of theInnovation Unioninitiative is to improve the conditions for innovation and better access to financing forresearch and innovation in Europe. Table 1 presents general guidelines of the European Commission's flagship Innovation Unioninitiative, which should help the EU to become more innovative in the future.

Table 1. General guidelines of the European Commission's flagship initiative Innovation Union

\begin{tabular}{|c|c|c|}
\hline GUIDELINES & & CHARACTERISTICS \\
\hline $\begin{array}{l}\text { STRENGTHENING } \\
\text { THE KNOWLEDGE } \\
\text { BASE AND } \\
\text { REDUCING } \\
\text { FRAGMENTATION }\end{array}$ & $\begin{array}{l}\text { Promoting excellence in } \\
\text { education and skills } \\
\text { development }\end{array}$ & $\begin{array}{l}\text { - create a perfect, modern } \\
\text { education system in all Member States, } \\
\text { - } \\
\text { attract and train young people to } \\
\text { become researchers and offer } \\
\text { internationally competitive research } \\
\text { careers to keep them in Europe and } \\
\text { attract the best fromabroad, } \\
\text { involve businesses in curricula } \\
\text { development and doctoral training so } \\
\text { that skills better match industry. }\end{array}$ \\
\hline
\end{tabular}




\begin{tabular}{|c|c|c|}
\hline & $\begin{array}{l}\text { Developingthe European } \\
\text { Research Area }\end{array}$ & $\begin{array}{l}\text { - avoid costly overlaps and } \\
\text { unnecessary duplication in national } \\
\text { research, } \\
\text { - simplify and harmonize } \\
\text { procedures relating to the system of } \\
\text { support for research and development, } \\
\text { invest in modern } \\
\text { infrastructure. }\end{array}$ \\
\hline & $\begin{array}{lr}\text { Focusing EU } & \text { funding } \\
\text { instruments } & \text { on } \\
\text { Innovation } & \text { Union } \\
\text { priorities } & \end{array}$ & $\begin{array}{l}\text { EU research and innovation } \\
\text { funding instruments need to be } \\
\text { streamlined and focused on the } \\
\text { objectives of Innovation Union, } \\
\text { - procedures of applying for } \\
\text { funding ought to be simplified. }\end{array}$ \\
\hline & $\begin{array}{l}\text { Promoting the European } \\
\text { Institute of Innovation } \\
\text { and Technology (EIT) as } \\
\text { a model of innovation } \\
\text { governance in Europe }\end{array}$ & $\begin{array}{l}\text { - } \\
\text { - bupportinnovativeresearch, } \\
\text { and innovative partners from research, } \\
\text { business and academia to work together } \\
\text { on major societal challenges, }\end{array}$ \\
\hline & $\begin{array}{l}\text { Enhancing access to } \\
\text { finance for innovative } \\
\text { companies }\end{array}$ & $\begin{array}{l}\text { - use public private partnerships } \\
\text { in an intelligent manner andimplement } \\
\text { changes to the regulatory framework. }\end{array}$ \\
\hline & $\begin{array}{l}\text { Creating a } \\
\text { innovation market }\end{array}$ & $\begin{array}{l}\text { - simplify patent procedures, } \\
\text { - introduce more stringent } \\
\text { targets and standards for the protection } \\
\text { of the environment, as a stimulus for } \\
\text { the creation of eco-innovation, } \\
\text { - increase the EU public } \\
\text { procurement of innovative products and } \\
\text { services. }\end{array}$ \\
\hline $\begin{array}{l}\text { GETTING GOOD } \\
\text { IDEAS TO MARKET }\end{array}$ & $\begin{array}{l}\text { Promoting openness and } \\
\text { capitalizing on Europe's } \\
\text { creative potential }\end{array}$ & $\begin{array}{l}\text { - deliver the so-called "fifth } \\
\text { freedom", which is free movement of } \\
\text { researchers and the free movement of } \\
\text { innovative ideas, } \\
\text { - intensify the transfer of } \\
\text { knowledge between business and } \\
\text { academia, } \\
\text { - increase the availability of the } \\
\text { results of publicly-funded research, } \\
\text { improvethe information } \\
\text { system research. }\end{array}$ \\
\hline $\begin{array}{l}\text { MAXIMISING } \\
\text { SOCIAL AND } \\
\text { TERRITORIAL } \\
\text { COHESION }\end{array}$ & $\begin{array}{l}\text { Spreading the benefits of } \\
\text { innovation across the } \\
\text { Union }\end{array}$ & $\begin{array}{l}\text { - avoid an "innovation divide" } \\
\text { between the most innovative regions } \\
\text { and the others, } \\
\text { - } \\
\text { between the most innovative regions in } \\
\text { the Member States and regions, which }\end{array}$ \\
\hline
\end{tabular}




\begin{tabular}{|c|c|c|}
\hline & & $\begin{array}{l}\text { have a lot of catching up to do in this } \\
\text { area. }\end{array}$ \\
\hline & Increasingsocialbenefits & $\begin{array}{l}\text { - development of social } \\
\text { innovation, use of ingenuity } \\
\text { humanitarian organizations, associations } \\
\text { and social entrepreneurs to find new } \\
\text { ways to meet social needs, } \\
\text { c creation of an innovative } \\
\text { public sector. }\end{array}$ \\
\hline $\begin{array}{l}\text { POOLING FORCES } \\
\text { TO ACHIEVE } \\
\text { BREAKTHROUGHS: } \\
\text { EUROPEAN } \\
\text { INNOVATION } \\
\text { PARTNERSHIPS }\end{array}$ & $\begin{array}{l}\text { Starting European } \\
\text { Innovation Partnerships } \\
\text { as part of the Innovation } \\
\text { Union flagship initiative }\end{array}$ & $\begin{array}{l}\text { - increase efforts related to } \\
\text { research and development, coordination } \\
\text { of investment in demonstration and } \\
\text { pilot projects, } \\
\text { - create partnerships for } \\
\text { innovation in key areas such as energy } \\
\text { security, transport, climate change, } \\
\text { energy efficiency, health and aging, } \\
\text { environmentally friendly production } \\
\text { methods and land management. }\end{array}$ \\
\hline $\begin{array}{l}\text { LEVERAGING OUR } \\
\text { POLICIES } \\
\text { EXTERNALLY }\end{array}$ & $\begin{array}{l}\text { Make Europe more } \\
\text { attractive to companies } \\
\text { and investors }\end{array}$ & $\begin{array}{l}\text { - createopportunities for } \\
\text { foreigners to remain in Europe, using } \\
\text { the capabilities of the "scientific visa } \\
\text { package" and of the "Blue Card", } \\
\text { strengtheninternational } \\
\text { cooperation in science and technology. }\end{array}$ \\
\hline & $\begin{array}{l}\text { Reforming research and } \\
\text { innovation systems }\end{array}$ & $\begin{array}{l}\text { - significant reforms to national } \\
\text { and regional policies are required, }\end{array}$ \\
\hline RESULTS & Measuring Progress & $\begin{array}{l}\text { - develop a new indicator } \\
\text { measuring the share of fast-growing } \\
\text { innovative companies in the economy, } \\
\text { build the European Innovation } \\
\text { Scoreboard to ensure the comparability } \\
\text { of the results of the EU and the } \\
\text { Member States in relation to a broad set } \\
\text { of indicators. }\end{array}$ \\
\hline & $\begin{array}{l}\text { A commitment by all to } \\
\text { turn Innovation Union } \\
\text { into reality }\end{array}$ & $\begin{array}{l}\text { a joint effort of the EU } \\
\text { institutions (the European Council, the } \\
\text { Commission and Parliament) and other } \\
\text { stakeholders (Member States, regions, } \\
\text { companies, etc.) is crucial for the } \\
\text { success of the Innovation Union. }\end{array}$ \\
\hline
\end{tabular}

Source: Own study based on: Communication from the Commission to the European Parliament, the Council, the European Economic and Social Committee and the Committee of the Regions, Europe 2020 the Flagship Initiative Innovation Union, SEC (2010) 1161, Brussels 2010, pp. 9-30.

In theInnovation Uniondocument there are also some obligations for the Member States, of which the following should be emphasized: 
- $\quad$ maintain collaboration between business and academia by creating "Knowledge Alliances",

- $\quad$ generate partnerships between higher education institutes, research centers and businesses, at regional, national and international level,

- develop indicators on aspects such as non-technological innovation, design, service innovation, and performance at regional level (European Commission, 2013).

The Innovation Unioninitiative sets a path for future development of innovative economy and states that integrated activities should be carried out at all levels: regional, national and community (Derlukiewicz, 2013). It is also important to develop different kinds of innovation, i.e: technological, process, organizational, marketing and social innovations.

Table 2. General characteristic of flagship initiative Digital Agenda for Europe

\begin{tabular}{|l|l|}
\hline PILLARS & CHARACTERISTICS \\
\hline T. DIGITAL SINGLE MARKET & $\begin{array}{l}\text { The goal is to boost the music download business, } \\
\text { establish a single area for online payments, and } \\
\text { protect EU consumers in cyberspace. }\end{array}$ \\
\hline $\begin{array}{l}\text { 2. INTEROPERABILITY AND } \\
\text { STANDARDS }\end{array}$ & $\begin{array}{l}\text { EU should guarantee that new IT devices, } \\
\text { applications, data repositories and services interact } \\
\text { faultlessly anywhere. The objective is to improve } \\
\text { standard-setting procedures and rise interoperability } \\
\text { as the keys to success. }\end{array}$ \\
\hline 3. TRUST AND SECURITY & $\begin{array}{l}\text { The aim is to increase safety ofonline transactions } \\
\text { by a number of proposed practical solutions, } \\
\text { including a coordinated European response to cyber- } \\
\text { attacks and reinforced rules on personal data } \\
\text { protection. }\end{array}$ \\
\hline 4. FAST AND ULTRA-FAST & $\begin{array}{l}\text { The goal is to develop faster Internet access and } \\
\text { ensure at least 50\% of European households access } \\
\text { to the Internet, whichwill help to usehigh definition } \\
\text { television or videoconferencing. }\end{array}$ \\
\hline 5. RESEARCH AND & $\begin{array}{l}\text { The objective is to transform the best research ideas } \\
\text { into marketable products and services. A secondary } \\
\text { INNOjective isto preserve Europe's competitive edge } \\
\text { obrough increased coordination and elimination of } \\
\text { Europe's fragmented research and scientific efforts. }\end{array}$ \\
\hline 6. ENHANCING DIGITAL & $\begin{array}{l}\text { The aim is to reduce the digital divide in EU and to } \\
\text { help disabled persons to deal with difficulties in } \\
\text { benefiting fully from new electronic content and } \\
\text { services. }\end{array}$ \\
\hline INCLUSION & $\begin{array}{l}\text { The objective is to reduce energy consumption, } \\
\text { support ageing citizens' lives, revolutionize health } \\
\text { services and deliver better public services by ICT. } \\
\text { The secondary goal is to digitize Europe's cultural } \\
\text { heritage providing online access for all. }\end{array}$ \\
\hline FOR EU SOCIETY & and
\end{tabular}

Source: Own study based on:bttp:// ec.europa.eu/digital-agenda/en 
Another initiative that is aimed at smart development is Digital Agenda for Europe.The Digital Agenda for Europe (DAE) aims to help Europe's citizens and businesses to get the most out of digital technologies.It contains 101 actions, grouped around seven priority areas, which are presented in tab.2. (European Commission, 2011)

The Digital Agenda includes 13 particular goals which summarize the digital transformation that theEU wants to achieve, among which the most important are:

- $\quad$ to cover the whole EU by broadband by 2013,

- $\quad$ to make $50 \%$ of the population use online shopping by 2015 ,

- $\quad$ to make $33 \%$ of SMEs make online sales or purchases by 2015 ,

- $\quad$ to make no differences between roaming and national tariffs by 2015 ,

- $\quad$ to increaseregular internet usage from $60 \%$ to $75 \%$ by 2015 ,

- $\quad$ to decrease the proportion of the population that has never used the internet from $30 \%$ to $15 \%$ by 2015

- $\quad$ to reduce energy use of lightingby $20 \%$ by 2020

Implementation of this flagship initiative will contribute to the development of asmart and digital society in EU in forthcoming years.

Another initiative that will help the EU to become smart and sustainable is Youth on the Move, whichaims at improving young people's education and employability and to decrease high youth unemployment.Concepts that should be considered include the following:

- to make education and training more appropriatefor young people's needs,

- $\quad$ to encourage more of them to take advantage of EU grants to study or train abroad,

- to encourage EU countries to take actions that will simplify the conversion from education to work.

Many initiatives and programs have been prepared to improve the quality of human capital until 2020, for example programs such as: Youth Guarantee, Erasmus +, Leonardo Da Vinci, Grundtvig, which boost skills and employability through education, training and sport. Between 2014-2020 these programs will provide opportunities for European citizens to study, train, gain work experience, and volunteerabroad.

During years 2014-2020 the three briefly described flagship initiatives (Innovation Union, Digital Agenda for Europe, Youth on the move) will contribute to the development of a smart economy in Europe. The other two initiatives, i.e.Resource efficient EuropeandAn industrial policy for the globalization era concentrate on supporting sustainable growth. The flagship initiative for a resource-efficient Europe supports the change towards a resource-efficient, low-carbon economy to accomplish sustainable growth.

The flagship initiative for a resource-efficient Europe delivers a long-term framework for activities in many policy areas, supporting policy agendas for climate change, energy, transport, industry, raw materials, agriculture, fisheries, biodiversity and regional development. This is to increase inevitability for investment and innovation and to guarantee that all appropriate policies factor in resource efficiency in a balanced manner. Here are some examples of synergies that are expected: 
- jobs generated in sectors connected to sustainable growth are often more secure, with high potential for exports and creation of economic value,

- activities on climate change and energy efficiency can increaseenergy security and decrease vulnerability to oil shocks,

- low-carbon technologies decrease emissions and often bring benefits in terms of air quality, noise and public health,

- improving the design of products can decrease the demand for energy and raw materials as well as make those products more long-lasting. (European Commission, 2011)

The next flagship initiative An integrated industrial policy for the globalization era, sets out a planaimed at boosting growth and jobs by maintaining and supporting a strong, diversified and competitive industrial base in Europe, offering well-paid jobs, and becoming more resource-efficient at the same time. To achieve this, some actions must be undertaken, i.e.:

- promoting industrial research on advanced manufacturing technologies in order to facilitate the modernization of the EU industrial base and providing a response to societal challenges,such asenergy efficiency and climate change,

- supportingactivities bringing together higher education and businesses to improve Europe's highly skilled workforce, such as an e-skills initiative focused on advanced ICT users in industry,

- boosting new business concepts and associated manufacturing technologies concentrated on the development of sustainable, user-driven design-based products different sectors,

- endorsing "smart specialization" (approach that concentrates efforts of particular regions on their strengths and potentially prosperous branches)in EU's regions to develop clusters and increase the innovation performance of regions (European Commission, 2012).

It is very important to emphasize that all entities (at the European, national and regional level)need to become involved in the process of implementation of Europe 2020 strategy and its flagship initiatives. This is the only way to achieve the goal of smart and sustainable economy in European Unionbefore 2020.

\section{Conclusion}

Development of smart and sustainable economy is a priority for the whole society in the European Union. All efforts at the community, national and regional level have to be undertaken to achieve this aim. Every single person should also support this process by: using safe energy and renewable energy, segregating waste, reducing water consumption, using public transport in order to reduce the number of private vehicles and maintain the quality of environment. Moreover, it is important to use natural recourses more efficiently and implement innovations in order to support smart and sustainable growth. 
Certainly, Europe 2020 strategy and its flagship initiatives show the direction for future development and are a good start for Europe to become smart and sustainable. However, it is important to implement in a regular way allthe principles and commitments included in the whole set of flagship initiatives. Otherwise, the smart and sustainable European economy will remain an unfulfilled dream.

Unfortunately, still in most of the world's economies the problems of sustainable development are not placed aspriorities of the world's policyprograms, even issues like climate change or mass starvation, do not lead the news or politicaldebates. (Hopwood B., Mellor M., O’Brien G., 2005). However, from year to year interestand awarenessof sustainable development among politicians and authorities of particular countries is growing.

\section{References:}

Derlukiewicz N. (2013), Prospects for innovation development in the European Union according to the new Europe 2020 strategy, [in:] Economy and Space, ed. S. Korenik, N. Derlukiewicz, Research Papers of Wroclaw University of Economics no. 324, Wroclaw, p.39-42.

European Commission (1999), European Spatial Development Perspective. Towards Balanced and Sustainable Development of the Territory of the European Union, Spatial Planning in Potsdam

European Commission (2010), Communication From The Commission Europe 2020- A strategy for smart, sustainable and inclusive growth, Brussels.

European Commission (2010), Europe 2020 the Flagship Initiative Innovation Union, p. 2-40

European Commission (2010),Communication From The Commission, An Integrated Industrial Policy for the Globalisation Era Putting Competitiveness and Sustainability at Centre Stage, European Commission, Brussels.

European Commission (2011), Communication From The Commission, A Resource-Efficient Europe Flagship Initiative Under The Europe 2020 Strategy, Brussels.

European Commission (2012), Connecting Smart and Sustainable Growth through Smart Specialisation. A practical guide for ERDF managing authorities,

European Commission (2013), State of the Innovation Union 2012. Accelarating change, DirectorateGeneral for Research and Innovation, p. 16.

Girardet H. (1999), Creating Sustainable Cities. Green: Dartington.

Hopwood B., Mellor M., O’Brien G. (2005), Sustainable Development: Mapping Different Approaches, Wiley InterScience, p. 48.European Commission (2010), Communication From The Commission Europe 2020- A strategy for smart, sustainable and inclusive growth, European Commission, Brussels.

http://ec.europa.eu/digital-agenda/digital-agenda-europe

http://ec.europa.eu/europe2020/index_en.htm

https://www.lynascorp.com/Pages/zero-harm-and-sustainable-development.aspx

Kuhn M., Tomassini M., Simons P. (2006), Towards a knowledge based economy? Knowledge and learning in European Educational Research, Peter Lang Publishing, New York, p.10.

Kukliński A. (2001), Knowledge-based economy. The challenge for Poland in the twenty-first century. KBN, Warszawa 2001, p.5.

Mempel-Śnieżyk A. (2013), Smart specialisation and clusters in economic growth [in:] Economy and Space, ed. S. Korenik, N. Derlukiewicz, Research Papers of Wroclaw University of Economics no. 324, Wroclaw, pp. 92-103.

OECD (1996), The knowledge-based economy, Paris, p. 9.

Runiewicz-Wardyn M.(2008), Knowledge-based economy as factor of competitiveness and economic growth, Leon Kozminski Academy of Entrepreneurship and Management, Warsaw, p.25.

Węgrzyn G.(2008) Innovation in the knowledge-based economy, [in:] New paradigms of spatial economy, (eds.) K. Miszczak, Z. Przybyła, Biuletyn KPZK, Zeszyt 236, PAN KPZK, Warszawa, p.198. 
Wells G.J.,Shuey, R.Kiely R. (2001) Globalization, Novinka, New York , p. 37.

World Bank (2012), Inclusive Green Growth Policies Tailored to Real-World Challenges, http://www.worldbank.org/depweb/english/sd.html

World Commission on Environment and Development (WCED) (1987). Our common future. Oxford: Oxford University Press, p. 30- 43. 